\title{
Biodiversity of Soil Macrofauna in Jelutong (Dyera lowii Hook.F) based Agroforestry System on Peatlands
}

\author{
Yanarita', Lies Indrayanti ${ }^{1 *}$, Johanna ${ }^{1}$, Afentina $^{1}$ \\ 1 Forestry Department, Faculty of Agriculture, Universitas Palangka Raya, J. Yos Sudarso, Palangka, Kec. Jekan \\ Raya, Kota Palangka Raya, Kalimantan Tengah 74874, Indonezja \\ * Corresponding author's e-mail: indayantilies@for.ac.id
}

\begin{abstract}
Soil macrofauna can be an indicator of changes to the ecosystem. This study aimed to investigate the biodiversity of soil macrofauna in jelutong-based agroforestry on peatlands. Line transect sampling was used, eight transects and 32 plots were established. The sample was collected using the hand sorting technique. Species diversity and species evenness were determined using Shannon-Wiener index, while species richness with Margalef index. This study found 2179 individuals of soil macrofauna that belong to six classes, nine orders, and 13 families. The Formicidae 1 family dominated the area (951 individuals), while Lumbricidae had the least number (13 individuals). This study indicates that the species diversity of soil macrofauna in the jelutong-based agroforestry on peatlands is moderate $\left(H^{\prime}=1.508\right)$ with moderate species evenness $(E=0.588)$ and very high species richness $(D M g=281.788)$. It implies the capacity of the system in providing suitable habitat for macrofauna, and that it can be a potential alternative for ecological restoration in peatlands.
\end{abstract}

Keywords: soil macrofauna, jelutong agroforestry, peatlands

\section{INTRODUCTION}

Peatlands are a unique ecosystem with incomparable diversity of flora and fauna. At the same time, they are environmentally-sensitive and easily damaged, while their restoration toward natural conditions often requires complex processes. Therefore, peatland management is deemed to be critical.

Indonesia has approximately 15 million hectares of peatlands, including 2,743,158 hectares in Central Kalimantan. On the basis of the analysis of peatland map published by the Indonesian Center for Agricultural Land Resources (BBDSLP), the peatlands in Central Kalimantan have various thickness with general classes of $0-2 \mathrm{~m}$ $(1,157,163 \mathrm{ha})$ and over $2 \mathrm{~m}(1,585,995 \mathrm{ha})$ (DLH Kalimantan Tengah, 2018).

Utilization of peatlands for agriculture, plantations and other sectors has the potential to significantly change the ecosystems and biodiversity of peatlands. Biodiversity denotes the wealth and variety of organisms living in an area. The higher the genetic variations, types, and species that live in a specific area, the greater the biodiversity of that area. Soil biodiversity reflects the living organisms occurring in the soil, both above or below ground. On the basis of body width, soil organisms can be divided into four groups: microfauna $(<0.1 \mathrm{~mm})$; mesofauna $(0.1-2 \mathrm{~mm})$ such as nematodes, collembola, and acarina; macrofauna $(2-20 \mathrm{~mm})$ such as earthworms, ants, and termites; and megafauna $(>2 \mathrm{~cm})$ such as snails (Nusroh, 2007). The presence and activities of soil macrofauna are a biological indicator of the changes to the ecosystem (Jurzenski et al. 2012). According to Wibowo and Slamet (2017), soil macrofauna play key roles in the improvement of the physical, chemical, and biological properties of soil that occurs in the process of immobilization and humification. Soil macrofauna are also essential in the improvement of soil aeration, water infiltration, and soil aggregation, and in the distribution of organic matter in the soil: attributes that urge the significance of soil macrofauna diversity (Njira and Nabwami 2013). 
The peat thickness of the peatland located in the Kalampangan Village, Palangka Raya City, Central Kalimantan, Indonesia, ranges from moderate to thick ( $>2 \mathrm{~m}$ ). The Kalampangan Village has a total area of 5000 ha that consists of 420 ha of settlement, 1000 ha of agricultural area/plantations, 3544 ha of home garden/pekarangan, and uncultivated land allocated for offices and infrastructure. This area was established as transmigration settlement in 1984, and has undergone a very intensive land management since then. Land conversion-related activities, however, lead to the decomposition or subsidence of the peat. Limin et al. (2000) claimed that the peatland surface in this area subsides by at least $1-3 \mathrm{~cm}$ per year.

The presence and activities of soil macrofauna can support the agroforestry system (Jose 2012), and can serve as an indicator of soil fertility (Velasquez and Lavelle, 2019) on peatlands. The abundance of macrofauna populations indicates the plants growing in these areas tend to produce a lot of litter-which eventually contributes to the availability of organic matter as it will be decomposed by fungi, bacteria and actinomycetes into essential nutrients for plants. The number and type of stands will affect the biodiversity of local macrofauna as suggested by Wibowo and Slamet (2017) on the variety of living organisms on the areas with mixed-species stands, rubber stands, pine stands, and without stands.

One of the land use patterns in Kalampangan is agroforestry, which is the combination of annual crops or perennial plants (i.e. jelutong) with seasonal or agricultural crops. Jelutong is a native species at peat swamp forest with a tree up to $25-45 \mathrm{~m}$ tall and up to $100 \mathrm{~cm}$ in diameter; it is characterized by thin crown, single-leaf, cylindrical trunk, and no buttresses. The outer bark is blackish gray with rough surface, and the plant exudes a thick, white, and milky sap when cut. The jelutong tree has a great economic value. The sap is used in the manufacturers of chewing gum, car tires, paints, adhesives and varnishes (KLHK, BPDASHL Barito, 2020), the timber is used in the production of plywood and wood pulp-which can be further processed into assorted finished products such as tables, drawing boards, wooden clogs, carvings, matchsticks, pencils, and paper (Tata et al. 2015). According to Indrayanti et al. (2019), the growth rate of jelutong in a natural forest reaches $0.77 \mathrm{~cm} /$ year, which is higher than the growth rate of other trees (i.e. meranti). Moreover, jelutong has been extensively used in forest and peatland rehabilitation (Bastoni 2015). Therefore, the existence of jelutong-based agroforestry on peatlands becomes an interesting topic, particularly in terms of the biodiversity of soil macrofauna in such land pattern. The present study aimed to investigate the soil macrofauna species and soil macrofauna biodiversity based on species diversity index, richness index, and evenness index in jelutong-based agroforestry on a peatland in the Kalampangan village.

\section{MATERIALS AND METHODS}

\section{Research site and time}

This study was conducted in jelutong-based agroforestry owned by the community of the Kalampangan village, Palangka Raya City, Central Kalimantan, Indonesia. It is a combination of jelutong trees and alternate seasonal crops of tomatoes (Solanum lycopercisum), maize (Zea mays), and chili (Capsicum frutescens). The research area is 1 ha, which is inundated in the rainy season, particularly during very heavy rainfall. However, the establishment of recent tertiary channels and trenches have reduced the period of inundation into 1-7 days. This study was conducted in September-October 2020. The primary data included macrofauna collected from the research site. The equipment consisted of gloves, sacks, hoes, tape measure/ruler, raffia rope, tweezers, $12 \times 20 \mathrm{~cm}$ clear plastic bags, shovels, machetes, sieves, tarpaulin, label paper, stationery, magnifying glass, camera, and 70\% alcohol (to preserve specimens).

\section{Data Collection}

\section{Plot Establishment}

Plot establishment was initiated by setting up eight line transects of $100 \mathrm{~m}$ along the jelutongbased agroforestry system. The distance between the line transects is $10 \mathrm{~m}$. Four plots were established with a size of $30 \times 30 \mathrm{~cm}$ into the depth of $20 \mathrm{~cm}$. The distance between the plots on the line transect is $20 \mathrm{~m}$. The total number of plots is 32 plots. 


\section{Macrofauna Sampling}

The sample was obtained using the hand sorting technique referring to Anwar and Ginting (2013), which is the direct collection of macrofauna in the research site with the equipment of hoe, shovel, and tweezers. The collected sample was stored in clear plastic bags for further identification, recording, and counting. The identification and classification of soil macrofauna was done based on Suin (2005).

\section{Data Analysis}

\section{Species Diversity Index}

The species diversity index was calculated using the Shannon-Wiener Index (Ludwig and Reynolds 1988). The index is calculated using the formula:

$$
H^{\prime}=\sum P i \ln (P i)
$$

The proportion of each species, $P i$, is calculated using the formula:

$$
P i=\frac{n i}{N}
$$

where: $H^{\prime}=$ diversity index,

$n i=$ number of individuals of each spe-

cies,

$N=$ total number of individuals in the site,

In = natural logarithm.

while the criteria are:

$H^{\prime}<1$ : indicates low species diversity,

$1<H^{\prime}<3$ : indicates moderate species diversity,

$H^{\prime}>3$ : indicates high species diversity.

\section{Species Evenness Index (E)}

The relative abundance with which each species is represented in an area is determined with the species evenness index (E). It is calculated using the formula (Magurran 2004):

$$
E=\frac{H^{\prime}}{\operatorname{InS}}
$$

where: $E=$ species evenness index,

$H^{\prime}=$ Shannon-Wiener species diversity index,

$$
S=\text { species richness. }
$$

Species evenness ranges from zero to one, with zero signifying no evenness and one signifying a complete evenness (Magurran 2004).

\section{Margalef Species Richness Index}

Species richness index is used to determine the species diversity based on the total number of the species in an ecosystem. It is calculated using the formula:

$$
D M_{g}=\frac{S-1}{\operatorname{Ln}(N)}
$$

where: $D M g=$ Margalef species richness index,

$S=$ number of species,

$N=$ total number of individuals of a particular species

The criteria for the Margalef species richness index are:

$<2.5=$ low species richness,

$2.5-4=$ moderate species richness, $>4=$ high species richness.

\section{RESULTS AND DISCUSSION}

\section{Identification of Macrofauna}

The observations of the types and number of individuals of soil macrofauna revealed there were six classes, nine orders, and 13 families. The highest number of individuals (951 individuals) found in the research site was classified into the Formicidae 1 family, while the least number (13 individuals) was classified into the Lumbricidae family. The total number of soil macrofauna found in the site was 2179 individuals. The taxonomic classification of soil macrofauna found on the jelutong-based agroforestry land in the Kalampangan Village is presented in Table 1.

The soil macrofauna found in the research site could be divided into three groups: aboveground group, belowground group, and aboveground-belowground group. As many as 12 families of aboveground macrofauna were identified, namely: Scolopendridae, Spirostreptidae, Clubionidae, Carabidae, Derodontidae, Scarabaeidae, Formicidae 1, Formicidae 3, Thripidae, Alynidae, Lygaeidae, and Achatinidae 1. They consisted of centipedes (Scutigera coleoptrata), rice ear bugs 
Table 1. Soil Macrofauna and Their Number in Jelutong-based Agroforestry in the Kalampangan Village

\begin{tabular}{|c|c|c|c|c|}
\hline No. & Class & Order & Family & $\mathrm{N}$ \\
\hline \multirow[t]{4}{*}{1} & Chaetopod & Oligochaeta & Lumbricidae & 13 \\
\hline & Chilopoda & Scolopendromorpha & Scolopendridae & 46 \\
\hline & Diplopoda & Spirostreptida & Spirostreptidae & 50 \\
\hline & Arachnida & Araneae & Clubionidae & 21 \\
\hline \multirow{8}{*}{2} & \multirow{8}{*}{ Insecta } & \multirow{3}{*}{ Coleoptera } & Carabidae & 25 \\
\hline & & & Derodontidae & 56 \\
\hline & & & Scarabaeidae & 25 \\
\hline & & \multirow{2}{*}{ Hymenoptera } & Formicidae 1 & 951 \\
\hline & & & Formicidae 3 & 797 \\
\hline & & Thysanoptera & Thripidae & 40 \\
\hline & & \multirow{2}{*}{ Hemiptera } & Alynidae & 69 \\
\hline & & & Lygaeidae & 42 \\
\hline 3 & Gastropoda & Pulmonata & Achatinidae 1 & 35 \\
\hline \multicolumn{4}{|c|}{ Total } & 2179 \\
\hline
\end{tabular}

(Leptocorisa oratorius Fabricius), fire ants (Solenopsis invicta), little black ants (Monomorium minimum), cross spiders (Araneus diadematus), millipedes, click beetles (Elateridae) rice bugs (Leptocorisa acuta), insects, great silver water beetle (Hydrophilus piceus), land snails (Achatina fulica), and scarab beetle (Scarabaeidae). The only belowground macrofauna found in the research site was red earthworms (Lumbricus rubellus) of Lumbricidae. Meanwhile, the soil macrofauna that live in both aboveground and belowground in the research site could be classified into five families of: Scolopendridae, Spirostreptidae, Thripidae, Formicidae 1, and Formicidae 3. They included Centipedis, millipedes, insects (Insectum), fire ants (Solenopsis invicta), and little black ants (Monomorium minimum).

The soil macrofauna that dominated the research site were insects: fire ants and little black ants that belong to the order Hymenoptera, the Formicidae 1 family (951 individuals) and the Formicidae 3 family (797 individuals). In general, the finding of this study is quite similar to the findings reported by Halwany (2011) and Harun (2011). Both studies revealed that the species belonging to the Formicidae family dominated the agroforestry system on peatland in Kalampangan, Tumbang Nusa. Ants are social insects, known for their regular colonies and nests. They have a caste system with different roles, namely worker, soldier, drone, and queen. The roles include decomposer, pollinator, aerator, predator, and biological indicator of environment conditions (Tawatao 2014). According to Frouz and Jilkova (2008), ants can increase soil nutrients by mediating the changes in soil chemistry through the presence of their nests in the soil. In addition, ants also affect the physical attributes of the soil and increase microbial activities. Moreover, they are found in almost all habitats (Sari et al. 2021), particularly in forests and open space lands (Carpenter et al. 2012), and their populations are relatively stable throughout the seasons and years. In addition, their large and relatively stable numbers situate them as important insect colonies in the ecosystem.

The potential of insects as biological indicators of changes in the ecosystem has been reported by Jurzenski et al. (2012). It includes the ants that are frequently used as biological indicator in the environmental assessment programs, such as forest fires, disturbances, deforestation, mining activities, waste disposal, and land use factors (Wang et al. 2000). Hakim et al. (2019) investigated the presence of macrofauna in the fire-effected peatland in the Forest Area for Special Purpose (KHDTK) Tumbang Nusa, Kalimantan, in which the area had undergone rehabilitation programs. The study reported the presence of seven families on land without revegetation, six families on land after 12 months revegetation, eight families on land after 21 months revegetation, and 10 families on land after 24 months revegetation. It implies that the longer the revegetation take places in an area, the greater the biodiversity in the area and the more stable the environment will be. A study was carried out in the fire-affected peatland and protected forest in the Kasang Padang Village, Bonaidarusalam Sub-district, Rokan Hulu Regency, Riau Province, in which acacia trees were planted as a rehabilitation effort. In these areas, as many as 2086 individuals belonging 
to nine families were identified, with Anoplolepis and Platyzosteria as the dominant families. In addition, only 229 individuals of 12 families (including Oryctes and Hermetia) were found in non-rehabilitated peatland, while 1140 individuals of 10 families were found in the protected forest which is overgrown by various types of plants (Gesriantuti et al. 2016). Anoplolepis belongs to the Formicidae sub-family while Platyzosteria belongs to the Insecta class. Oryctes belongs to the Scarabaeidae family and Hermetia belongs to the Stratiomyidae family.

Overall, the finding of this study on the biodiversity of soil macrofauna in jelutong-based agroforestry on peatland is insignificantly different to the findings of previous similar studies. They could identify nine to twelve families in the respective research sites. Moreover, this study also found similar families as reported by previous studies, except for the Hermetia family that could be found in Riau. The different types of soil macrofauna in research sites are very likely influenced by the different types of vegetation that grow as their habitats.

\section{Biodiversity of Macrofauna}

The biodiversity of soil macrofauna in jelutong-based agroforestry on peatland was determined based on the species diversity index, species richness index, and species evenness index as presented in Table 2.

The analysis of species diversity index indicates that the soil macrofauna diversity in jelutong-based agroforestry in the Kalampangan village can be classified as 'moderate' $(H$ ' $=$ 1.509). This finding verifies Harun (2016) on the 'moderate' diversity of soil macrofauna in jelutong-based agroforestry in the Kalampangan village $\left(H^{\prime}=1.8\right)$. Nevertheless, the soil macrofauna diversity in jelutong-based agroforestry is higher than that in Industrial Plantation/HTI of acacia as reported by Komala et al. (2016). The study analyzed the macrofauna diversity in acacia HTI in Riau, and found that the soil macrofauna diversity in HTI of 6 months acacia and 48 months acacia is 'low' $(H$ ' $=0.87$ and 0.78 , respectively). Handayani and Winara (2020) reported that the macrofauna diversity in secondary peatland in West Kalimantan was 'moderate' $\left(H^{\prime}=2.09\right)$, while the macrofauna diversity in oil palm plantations was lower $\left(H^{\prime}=0.73\right)$. The study conducted by Gesriantuti et al. (2016) in the Kasang Padang Village, Bonaidarusalam Sub-district, Rokan Hulu District, Riau Province found that the macrofauna species diversity of fire-affected peatland with monoculture acacia rehabilitation program $\left(H^{\prime}=0.48\right)$ was higher than the species diversity of the heterogeneous protected forest $\left(H^{\prime}=0.31\right)$. Meanwhile, Qirom et al. (2019) investigated the species diversity of a peat swamp forest in Sebangau National Park $\left(H^{\prime}=0.309\right)$. The species diversity index of an area differs from others, signifying the difference in the number of species and the biodiversity level of the habitats.

The analysis of the species evenness index indicated that the species evenness of soil macrofauna in jelutong-based agroforestry in the Kalampangan village was moderate $(E=0.588)$. Meanwhile Sugiarto et al. (2017) investigated the

Table 2. Soil Macrofauna Biodiversity in Jelutong-based Agroforestry in Kalampangan Village

\begin{tabular}{|c|l|c|c|c|c|c|c|}
\hline No & \multicolumn{1}{|c|}{ Family } & $\mathrm{Ni}$ & $\mathrm{Pi} / \mathrm{N}$ & Ln Pi/N & $H^{\prime}$ & $E$ & $D M g$ \\
\hline 1 & Lumbricidae & 13 & 0.006 & -5.116 & 0.031 & 0.012 & 1.561 \\
\hline 2 & Scolopendridae & 46 & 0.021 & -3.863 & 0.081 & 0.032 & 5.854 \\
\hline 3 & Spirostreptidae & 42 & 0.019 & -3.963 & 0.075 & 0.029 & 5.334 \\
\hline 4 & Clubionidae & 34 & 0.016 & -4.135 & 0.066 & 0.026 & 4.293 \\
\hline 5 & Carabidae & 50 & 0.023 & -3.772 & 0.087 & 0.034 & 6.375 \\
\hline 6 & Derodontidae & 56 & 0.026 & -3.650 & 0.095 & 0.037 & 7.155 \\
\hline 7 & Scarabaeidae & 21 & 0.01 & -4.605 & 0.046 & 0.018 & 2.602 \\
\hline 8 & Formicidae 1 & 797 & 0.366 & -1.005 & 0.368 & 0.143 & 103.557 \\
\hline 9 & Formicidae 3 & 951 & 0.436 & -0.830 & 0.362 & 0.141 & 123.591 \\
\hline 10 & Thripidae & 69 & 0.032 & -3.442 & 0.110 & 0.043 & 8.847 \\
\hline 11 & Alynidae & 40 & 0.018 & -4.017 & 0.072 & 0.028 & 5.074 \\
\hline 12 & Lygaeidae & 35 & 0.016 & -4.135 & 0.066 & 0.026 & 4.423 \\
\hline 13 & Achatinidae 1 & 25 & 0.011 & -4.510 & 0.050 & 0.019 & 3.122 \\
\hline & Total & 2179 & 1 & -47.044 & 1.509 & 0.588 & 281.788 \\
\hline
\end{tabular}

Data source: Primary data analysis. Description: $H^{\prime}$ (diversity index); $E$ (evenness index); $D M g$ (species richness). 
condition of peatland in Pelalawan, Riau, four months after the fire, and found that the species evenness index of macrofauna was close to one, implying all species had almost the same level of evenness or there was no dominant species. The difference in the species evenness of macrofauna in jelutong-based agroforestry shows that each family has a different composition of the number of individuals. Evenness is an indicator of the dominance of species in a community. The difference in the evenness index of soil macrofauna indicates the dominance of a species or the high number of individuals of a species in a community. Rosa et al. (2019) carried out a study on peatlands in the area of Faculty of Forestry, Universitas Tanjungpura, Pontianak, revealing the species evenness of ants in the research site $(E=0.740)$. Similarly, Qirom et al. (2019) investigated the evenness of macrofauna in the peat swamp forest in Sebangau National Park, Central Kalimantan $(E=0.410)$.

The species richness index of soil macrofauna in the jelutong-based agroforestry in the Kalampangan village was very high $(D M g=$ 281.788 ), indicating that based on the number of different species represented in the peatland, the diversity of soil macrofauna in the Kalampangan village was very high. The highest index was found in Formicidae 1 (fire ants (Solenopsis invicta)) and Formicidae 3 (little black ants (Monomorium minimum)), amounting to 123.591 and 103.557 , respectively. The difference in the value of species richness index can be influenced by the physical factor, biotic factor, and the availability of food. Considering that ants are arthropods which serve as decomposers of organic matter, the abundance of litter on peatland will attract them to invade the area. In addition, thick litter potentially creates a microclimate suitable for the presence of ants (Haneda and Yuniar, 2015). Moreover, ants tend to live in colonies and rapidly dominate an area. According to Borror et al. (1992), the feeding habits among the ants also vary. Many ants are carnivores that prey on other animals (live or dead), while some eat plants, mushrooms, and nectars. While in the nest, ants often eat the secretions of other individuals, and exchange food between individuals. Handayani and Winara (2020) compared the species richness of macrofauna on the secondary peatland and oil palm plantation in West Kalimantan, claiming that the species richness of macrofauna in the secondary forest $(D M g=4.01)$ was higher than that in the oil palm plantation $(D M g=1.42)$. Meanwhile, Rosa et al. (2019) reported the species richness of ants on peatland in the area of Faculty of Forestry, Universitas Tanjungpura, Pontianak, was high $(D M g>4)$.

\section{CONCLUSIONS}

The biodiversity of soil macrofauna in jelutong-based agroforestry on the peatland as indicated by the findings of this show that the low species diversity, moderate species evenness, and very high species richness. The most common macrofauna found on peatland are the Insecta class of the Formicidae family 3 (little black ants (Monomorium minimum)) as they live in colonies with abundant food sources. The findings of this study indicate that jelutong-based agroforestry on peatlands provides a suitable habitat for soil macrofauna.

\section{Acknowledgments}

We thank the International Center for Research in Agroforestry (ICRAF) for the opportunity to contribute in the agroforestry-based research program. We also thank for all the assistances given during the data collection, analysis, and reporting.

\section{REFERENCES}

1. Anwar EA, Ginting RCB. 2013. Mengenal fauna tanah dan cara identifikasinya. Jakarta: IAARD Press.

2. Bastoni B. 2014. Budidaya jelutung rawa (Dyera lowii Hook.F). Palembang: Balai Penelitian Kehutanan Palembang.

3. Borror DJ, Johnson NF, Triplehorn CA. 1992. Pengenalan pelajaran serangga. Yogyakarta: UGM Press.

4. Carpenter D, Hammond PM, Sherlock E, Lidgett A, Leigh K, Eggleton P. 2012. Biodiversity of soil macrofauna in the New Forest: A benchmark study across a national park landscape. Biodiversity and Conservation 21(13), 3385-3410.

5. DLH Kalimantan Tengah. 2018. Laporan kinerja APBN-tugas pembantuan restorasi gambut Dinas Lingkungan Hidup Provinsi Kalimantan Tengah. Palangka Raya.

6. Frouz J, Jilkova V. 2008. The effect of ants on soil properties and processes (Hymenoptera: Formicidae). Myrmecological News 11, 191-199. 
7. Gesriantuti N, Trantiati R, Badrun Y. 2016. Keanekaragaman serangga permukaan tanah pada lahan gambut bekas kebakaran dan hutan lindung di Desa Kasang Padang, Kecamatan Bonaidarusalam, Kabupaten Rokan Hulu, Provinsi Riau. Photon: Jurnal Sain dan Kesehatan 7(01):147-155. (Available from https://ejurnal.umri.ac.id/index.php/photon/article/ download/569/281)

8. Hakim SS, Halwany W, Rachmanadi D. 2019. Fungi and macrofauna community in post-fire peatland in Central Kalimantan. Indonesian Journal of Forestry Research 6(2), 107-116. (Available from http:// ejournal.forda-mof.org/ejournal-litbang/index.php/ IJFR/article/viewFile/4757/4814)

9. Halwany, W. 2011. Keragaman makrofauna tanah sebagai indikator pengolahan lahan (Studi kasus pada lahan tanaman jelutong rawa (Dyera polyphylla)). Prosiding Ekspose Hasil Penelitian: Dukungan BPK Banjarbaru dalam Pembangunan Kehutanan di Kalimantan (pp. 87-95). Pusat Litbang Peningkatan Produktivitas Hutan.

10. Handayani W, Winara A. 2020. Keanekaragaman makrofauna tanah pada beberapa penggunaan lahan gambut. Jurnal Agroforestri Indonesia 3(2), 77-88.

11. Haneda NF, Yuniar N. 2015. Komunitas semut (Hymenoptera: Formicidae) pada empat tipe ekosistem yang berbeda di Desa Bungku Provinsi Jambi. Jurnal Silvikultur Tropika 6(3), 203-209.

12. Harun MK. 2011. Analisis pengembangan jelutong dengan sistem agroforestri untuk memulihkan lahan gambut terdegradasi di Provinsi Kalimantan Tengah. (Available from https://repository.ipb.ac.id/ handle/123456789/53109 pada 8 June 2019

13. Harun MK. 2016. Agroforestry berbasis jelutung rawa solusi sosial ekonomi, dan lingkungan pengolahan lahan. (Available from https://issuu.com/gunawanwotanngare/docs/ agroforestry_berbasis_jelutung_rawa)

14. Indrayanti L, Rotinsulu JM, Yanarita Y, Sosilawaty S. 2019. Peat swamp forest: Management and development of indigenous species to support economic local people at periphery forest (Case study in Central Borneo, Indonesia). Journal of Ecological Engineering 20(4).

15. Jose S. 2012. Agroforestry for conserving and enhancing biodiversity. Agroforest System 85:1-8.

16. Jurzenski J, Albrecht M, Hoback WW. 2012. Distribution and diversity of ant genera from selected ecoregions across Nebraska. The Prairie Naturalist 44(1), 17-29.

17. KLHK-BPDASHL Barito. 2020. Jelutung - Kalimantan Tengah. (Available from http://bpdasbarito. or.id/jelutung-kalteng/) (Accessed on 21 March 2021)

18. Komala DF, Djajakirana G, Suwardi. 2016. Kelimpahan dan keanekaragaman makrofauna tanah pada tiga penggunaan lahan gambutdi Teluk Meranti, Kabupaten Pelalawan, Provinsi Riau. (Available from https:// repository.ipb.ac.id/handle/123456789/85133)

19. Limin SH, Tampung NS, Patricia EP, Darung U, Layuniyati L. 2000. Konsep pemanfaatan hutan rawa gambut di Kalimantan Tengah. Seminar Nasional Pengelolaan Hutan Rawa Gambut dan Ekspos Hasil Penelitian di Lahan Basah. Balai Teknologi Reboisasi Banjarbaru, Istana Barito Banjarmasin.

20. Ludwig JA, Reynolds JF. 1988. Statistical ecology: a primer on methods and computing. New York: Wiley.

21. Magurran AE. 2004. Measuring biological diversity. Oxford: Blackwell Sciene.

22. Njira KOW, Nabwami J. 2013. Soil management practices that improve soil health: elucidating their implications on biological indicators. Journal of Animal \& Plant Sciences 18, 2750-2760.

23. Nusroh Z. 2007. Studi diversitas makrofauna tanah di bawah beberapa tanaman palawija yang berbeda di lahan kering pada saat musim penghujan. Jurnal Penelitian UNS Surakarta.

24. Qirom MA, Halwany W, Rahmanadi D, Tampubolon AP. 2019. Studi biofisik pada lanskap hutan rawa gambut di Taman Nasional Sebangau: kasus di Resort Mangkok. Jurnal Ilmu Pertanian Indonesia 24(3), 188-200.

25. Rosa N, Dewantara I, Prayogo H. 2019. Keanekaragaman semut (Famili Formicidae) pada lahan gambut di lingkungan gedung baru Fakultas Kehutanan Universitas Tanjungpura Pontianak. Jurnal Hutan Lestari, 7(2).

26. Sari RW, Yolanda R, Purnama AA. 2021. Jenis-jenis semut (Hymenoptera: Formicidae) pada perkebunan kelapa sawit di sekitar Kampus Universitas Pasir Pengaraian. (Available from https://media.neliti. com/media/publications/110326-ID-jenis-jenissemut-hymenoptera-formicidae.pdf_)

27. Sugiarto A, Wawan W, Wardati W. 2017. Pengaruh kebakaran dan waktu setelah terbakar terhadap makrofauna tanah gambut di Kecamatan Teluk Meranti Kabupaten Pelalawan. JOM Faperta 4(2). (Available from https://media.neliti.com/media/ publications/200923-pengaruh-kebakaran-danwaktu-setelah-ter.pd)

28. Suin NM. 2005. Metode ekologi. Padang: Universitas Andalas.

29. Tata HL, Bastoni B, Sofiyuddin M, Mulyoutami E, Perdana A, Janudianto J. 2015. Jelutung rawa: teknik budidaya dan prospek ekonominya. ICRAF Southeast Asia Regional Program. Bogor Indonesia: ICRAF. p 62.

30. Tawatao NB. 2014. Basic biology and ecology of Ants. (Available from http://www.antbase. net/english/ants-of-southeast-asia/ecology/basic 
antbiology.html) (Accessed on 20 March 2021)

31. Velasquez E, Lavelle P. 2019. Soil macrofauna as an indicator for evaluating soil based ecosystem services in agricultural landscapes. Acta Oecologica 100, 1-18. (Available from https://doi.org/10.1016/j. actao.2019.103446)

32. Wang C, Strazanac J, Butler L. 2000. Abundance, diversity, and activity of ants (Hymenoptera:
Formicidae) in oak - dominated mixed Appalachian forest treated with microbial pesticides. Environmental Ecology 29(3), 579-586.

33. Wibowo C, Slamet SA. 2017. Soil macrofauna diversity on various types of stands in Silicas' post-mining land in Holcim Educational Forest, Sukabumi, West Java. Jurnal Silvikultur Tropika 08(1), 26-34. (Available from https://journal.ipb.ac.id) 